Halaman 9-16

\title{
Pengaruh Model Pembelajaran Predict Observe Explain Write terhadap Kemampuan Berpikir Kritis Siswa Kelas X SMA Negeri 2 Sukoharjo Tahun Pelajaran 2012/2013
}

\author{
The Influence of Predict Observe Explain Write Towards of Critical Thinking Skills \\ and in X Degree SMA N 2 Sukoharjo in academic year on 2012/2013
}

\author{
Hikmah Wardatun, Sri Dwiastuti, Puguh Karyanto \\ Pendidikan Biologi FKIP Universitas Sebelas Maret \\ Email: chim_ah@yahoo.com
}

Diterima 4 Agustus 2013, disetujui 6 September 2013

\begin{abstract}
This research aimed to find out whether or not there is an effect of Predict Observe Explain Write on the critical thinking ability of the X graders of SMA Negeri 2 Sukoharjo in academic year on 2012/2013. This study was a quasi experiment research. Posstet only nonequivalent control group design is used in this research. The population of research was all X grades of SMA Negeri 2 Sukoharjo in academic year 2012/2013 consisiting 285 students. Cluster sampling.is used to this research. The result of cluster sampling is choosen for X6 as experimental gruop and X7 as control group. Predict observe explain write model is applied in experimental group and conventional model is applied in control group. The data was collected by using critical thinking test, observastion sheet, and school documents. The data were analyzed by t-test. The results of this research shows that the mean of student's capability of critical thinking in experiment class higher than control class, it was 70,41 for experiment class and 61,98 for control class. The result of hypothesis is analyzed by t-test and it gets significant value 0,000 (sig.<0,05), so the Predict Observe Explain Write model has effect toward student's capability of critical thinking. This conclution is the application of Predict Observe Explain Write models has real effect toward critical thinking ability of $\mathrm{X}$ grade students at SMA Negeri 2 Sukoharjo in academic year on 2012/2013.
\end{abstract}

Key Words: Predict Observe Explain model, Think Talk Write strategy, Critical Thinking Ability

\section{Pendahuluan}

Berpikir kritis merupakan kemampuan berpikir yang dimiliki untuk memecahkan masalah secara sistema-tis. Tujuan dari berpikir kritis adalah untuk mencapai pemahaman yang mendalam yaitu pemahaman yang mengungkapkan makna di balik suatu kejadian (Johnson, 2010). Menurut Ennis berpikir kritis itu menyangkut pemecahan masalah, pengambilan keputusan, menganalisis dan melakukan penelitian ilmiah.

Kemampuan berpikir kritis merupakan kemampuan untuk mema-hami masalah dan pendapat, kemampuan menyeleksi informasi dan hipotesis yang penting serta relevan untuk menyelesaikan masalah serta kemam-puan untuk menarik kesimpulan yang valid (Amri \& Ahmadi, 2010). Kemampuan berpikir kritis menurut Facione (2013) meliputi interpretation, analysis, evaluation, in- 
ference, explanation, dan self-regulation. Berpikir kritis dapat diajarkan melalui kegiatan laboratorium, penemuan, pekerjaan rumah yang dapat mengembangkan kemampuan berpikir kritis, dan ujian yang dirancang untuk membangun kemampuan berpikir kritis. Kemampuan berpikir kritis dapat ditingkatkan melalui diskusi kelompok yang tertata dan dibimbing langsung oleh guru. Pertanyaan-pertanyaan tingkat tinggi (high level question) dapat mendorong pemikiran kritis yang lebih mandalam.

Berpikir kritis sebagai bagian dari ketrampilan berpikir perlu dimiliki oleh setiap anggota masyarakat, sebab banyak sekali persoalan-persoalan dalam kehidupan yang harus dikerjakan dan diselesaikan (Wijaya, 2007). Kemampuan berpikir kritis yang rendah menyebabkan peserta didik akan mengalami kesulitan ketika dihadapkan pada suatu permasalahan yang konkrit dalam kehidupan sehari-hari.

Berpikir kritis mempunyai peranan penting dalam kehidupan, sehingga dijadikan sebagai pedoman penilaian dalam menentukan kelulusan peserta didik. Pendapat tersebut sesuai dengan standar kompetensi lulusan satuan pendidikan (SKL-SP) untuk SMA yang tercantum dalam peraturan menteri pendidikan nasional (Permendiknas) nomor 23 tahun 2006 yang menyebutkan bahwa siswa SMA harus mampu menunjukkan kemampuan berpikir kritis, logis, kreatif, dan inovatif dalam mengambil keputusan.

Marzano yang menyatakan bahwa sasaran utama siswa bersekolah adalah untuk meningkatkan kemampuan berpikir kritisnya (Slavin, 2005), namun pada kenyataannya siswa di sekolah tidak mempunyai kesempatan untuk mengembangkan kemampuan berpikir kritisnya sehingga kemampuan berpikir kritis siswa cenderung rendah. Hal tersebut ditunjukkan oleh beberapa penelitian terkait kemampuan berpikir kritis yaitu Dwiyanti \& Darsati yang menunjukan bahwa kemampuan untuk menarik kesimpulan dari hasil menyelidiki pada kelas X SMA termasuk kategori rendah dan kemampuan memberikan penjelasan dari hasil pertimbangan pada siswa kelas XI termasuk kategori sangat kurang, padahal seseorang yang berpikir kritis mampu menarik kesimpulan dan memberikan penjelasan. Hasil penelitian Pratama (2012) yang menunjukkan bahwa kesiapaan mahasiswa untuk menemukan pengetahuan terbaik dari suatu konteks, berani bertanya, dan jujur serta objektif dalam mencari informasi masih rendah, padahal seseorang yang mempunyai kesiapan untuk menemukan pengetahuan terbaik dari suatu konteks, berani bertanya, jujur serta objektif cen- 
derung mempunyai sifat berpikir kritis. Hasil-hasil penelitian tersebut menunjukkan bahwa kemampuan berpikir siswa dan mahasiswa masih rendah. Hal tersebut didukung oleh survey tim IMSTEP-JICA yang menyatakan bahwa siswa-siswi di kota Bandung mengalami kesulitan jika dihadapkan pada persoalan yang memerlukan kemampuan berpikir kritis seperti membuktikan pemecahan masalah yang memerlukan penalaran dan menghubungkan antara data-data dan fakta yang ditemukan (Fachruazi, 2011).

Dari uraian diatas maka pengembangan kemampuan berpikir kritis perlu dioptimalkan. Salah satunya dengan menerapakan pendekatan, model, strategi yang tepat. Model, strategi, dan pendekatan yang dapat mengembangkan kemampuan berpikir kritis diantaranya: Experiential Learning (Lestari, 2012), pembelajaran inkuiri (Praptiwi, 2007), strategi pembelajaran Blended Learning (Cahyadi, 2011), Problem Based Learning (Adnyana, 2008), Predict Observe Explain (Suyanto, 2012), Think Talk Write (Hidayat, 2011), dan Predict Observe Explain Write (Samosir, 2010).

Kelebihan model Predict Observe Explain Write adalah 1) siswa menjadi aktif dan terlibat langsung dalam pembelajaran; 2) siswa menjadi lebih kreatif terutama saat mengemukakan prediksi; 3) pembelajaran lebih menarik karena siswa bisa melakukan pengamatan secara langsung; 4) Dapat melatih siswa mengkomunikasikan atau menjelaskan keterkaitan antara prediksi dan hasil observasi pada orang lain, sehingga kegiatan pembelajaran akan lebih bermakna dan melatih siswa untuk berpikir kritis, 5) siswa mengkonstruk sendiri pengetahuannya.

\section{Metode Penelitian}

Penelitian ini dilaksanakan di SMA Negeri 5 Surakarta pada semester genap tahun pelajaran 2012/2013. Penelitian ini termasuk kuasi eksperimen. Desain penelitian adalah Posttest Only Non-equivalent Control Group Design dengan menggunakan kelompok eksperimen (penerapan model Predict Observe Explain dengan strategi Think Talk Write) dan kelompok kontrol (penerapan pembelajaran ceramah bervariasi).

Populasi dalam penelitian ini adalah seluruh siswa kelas X SMA Negeri 2 Karanganyar. Teknik pengambilan sampel dengan cluster sampling. Hasil pemilihan sampel menetapkan kelas X6 dengan siswa sebanyak 35 orang sebagai kelompok eksperimen yang menerapkan model pembelajaran Predict Observe Explain dengan strategi Think Talk Wrute dan kelas X7 dengan siswa sebanyak 35 orang se-bagai 
kelompok kontrol yang mene-rapkan pembelajaran ceramah bervariasi.

Variabel bebas berupa model pembelajaran Predict Observe Explain dengan strategi Think Talk Write dan variabel terikat adalah kemampuan berpikir kritis. Teknik pengumpulan data yang digunakan dalam penelitian ini adalah dokumentasi, tes dan observasi. Metode dokumentasi pada penelitian ini berupa dokumen ulangan harian biologi semester ganjil sebagai bahan acuan yang digunakan untuk mengetahui keseimbangan uji normalitas dan homogenitas populasi berdasarkan nilai hasil belajar biologi pada populasi penelitian. Metode tes digunakan untuk mengambil data kemampuan berpikir kritis. Metode observasi dalam penelitian ini digunakan untuk mengukur keterlaksanaan sintaks pembelajaran.

Tes uji coba pada instrumen penelitian dilakukan untuk mengetahui validitas produk moment dan reliabilitas soal tes kemampuan berpikir kritis. Selain validasi produk moment, instrumen juga divalidasi konstruk oleh ahli.

Analisis data pada penelitian dengan menggunakan uji $t$. Sebelumnya dilakukan uji normalitas menggu-nakan uji Kolmogorov-Smirnov dan uji homogenitas dengan uji Levene's.

\section{Hasil dan Pembahasan}

Hasil analisis menunjukan bahwa sig. $0,00<0,01$, hal ini menunjukkan bahwa penerapan model Predict Observe Explain Write berpengaruh sa-ngat nyata terhadap kemampuan ber-pikir kritis siswa.

Pembelajaran dengan model Prdict Observe Explain Write menimbulkan interaksi yang positif antara siswa dan guru dalam pembelajaran. Hal ini terlihat pada saat guru membimbing siswa untuk menemukan konsep-konsep siswa pada materi pencemaran lingkungan. Pembelajaran Predict Observe Explain Write terdiri dari tahapan-tahapan proses belajar yang dapat meningkatkan kemampuan berpikir kritis siswa. Model pembe-lajaran Predict-Observe-Explain me-nuntut siswa untuk aktif dan mengutarakan sebanyak-banyaknya mengenai apa yang mereka ketahui dan pada akhirnya mereka merekonstruksi dan mengombinasikannya dengan pengetahuan awal mereka dengan pengetahuan baru yang mereka dapatkan (Liew, 2004). Pada tahap observe terjadi perbaikan konsep jika antara prediksi dan hasil observasi tidak sesuai, dan konsep akan semakin matang ketika prediksi dan hasil observasi sesuai.

Tahap-tahap pada pembelajaran pada kelas X-6 atau kelas eksperimen ini 
adalah tahap pertama pada pembelajaran ini yaitu Predict (prediksi). Pada tahap ini siswa dibimbing oleh guru untuk mengungkapkan pengetahuan awal mereka dengan membuat prediksi atau hipotesis. Siswa diminta mengungkapkan pengetahuan awal mereka dengan membuat rancangan percobaan mengenai pencemaran lingkungan berdasarkan alatalat yang telah disediakan oleh guru sesuai dengan bimbing-an guru. Hal ini memberikan kesempatan pada siswa untuk mengembangkan kemampuan berpikir kritisnya. Aspek berpikir kritis yang dikembangkan pada tahap ini adalah Interpretasi

Tahap kedua dari pembelajaran ini adalah Observe (observasi). Pada tahap ini siswa melakukan pengamatan (observasi) dengan melakukan percobaan mengenai pencemaran lingkung-an sesuai dengan rancangan percobaan yang telah dibuat sendiri oleh siswa secara berkelompok yang sebelumnya sudah disetujui oleh guru. Kegiatan observasi ini diharapkan mampu menunjang pemahaman konsep siswa (Fransiska, 2009) Melalui tahap ini siswa bisa mengetahui secara langsung apakah prediksi yang mereka buat sesuai atau tidak sesuai dengan Kenyataan. Dengan melihat secara langsung dalam melakukan percobaan maka hal ini membuat siswa lebih memahami masalah pencemaran lingkungan dan dampak yang ditimbulkan pencemaran terhadap lingkungan.

Tahap yang ketiga yaitu Ex-plain. Pada tahap ini siswa menjelaskan mengenai kesesuaian antara prediksi yang telah mereka buat dengan hasil observasi (kenyataan). Tahap ini dilakukan berdiskusi secara berkelompok 5-6 orang. Selanjutnya siswa mempresentasikan hasil diskusi yang telah mereka lakukan di depan kelas dan siswa yang lain menanggapi apa yang disampaikan oleh kelompok yang presentasi. Siswa yang tidak presentasi berhak mengajukan pertanyaan kepada kelompok presentasi. Tahap Explain ini memungkinkan siswa mengembangkan aspek berpikir kritis menurut Facione yaitu evaluation, ex-planation, dan inference.

Tahap yang terakhir yaitu Write. Pada pertemuan pertama siswa diminta untuk membuat laporan praktikum sesuai dengan praktikum yang telah dilakukan, kemudian pada pertemuan kedua siswa membuat makalah mengenai upaya yang dilakukan untuk mengatasi pencemaran lingkungan. Menulis merupakan cara untuk melatihkan kemampuan berpikir kritis sis-wa karena menulis mendorong siswa untuk mengorganisasikan pemikiran, mengevaluasi data yang diperoleh sis-wa, dan menyampaikan kesimpulan 
yang mereka peroleh (Jensen, 2012). Pada tahap ini aspek kemampuan berpikir kritis yang muncul adalah aspek evaluation, explanation, dan inference.

Proses belajar mengajar di kelas X-7 sebagai kelas kontrol menggunakan metode yang biasa digunakan guru dalam mengajar yaitu ceramah bervariasi. Pertemuan pertama guru menyampaikan materi dengan ceramah dengan membaca slide powerpoint, sedangkan siswa hanya mendengarkan dan mencatat apa yang disampaikan oleh guru. Selanjutnya siswa melakukan praktikum mengenai pencemaran lingkungan sesuai dengan prosedur percobaan yang telah dibuat oleh guru. Perbedaan praktikum antara kelas kontrol dan kelas eksperimen adalah pada kelompok kontrol siswa melakukan percobaan sesuai prosedur perco-baan yang disediakan guru sedangkan pada kelas eksperimen percobaan yang dilakukan sesuai dengan prosedur percobaan yang telah mereka buat sendiri. Kelas eksperimen lebih siap dalam melakukan praktikum karena mereka sendiri yang membuat prosedur percobaan. Proses pembelajaran pada kelas kontrol cenderung monoton karena siswa cenderung pasif. siswa hanya mendengarkan penjelasan dari guru dan sesekali menjawab pertanya-an yang diajukan guru. Pertemuan kedua guru meminta siswa melakukan observasi di lingkungan sekolah kemudian mempresentasikannya. Pembelajaran dengan metode ceramah kurang memberikan kesempatan siswa untuk mengembangkan kemampuan berpikirnya sehingga kemampuan berpikir kritis siswa kelas kontrol lebih rendah dibandingkan kelas eksperimen.

Hasil penelitian ini membuktikan bahwa model pembelajaran Predict $\mathrm{Ob}$ serve Explain Write dapat me-ningkatkan kemampuan berpikir kritis siswa. Ratarata nilai kemampuan ber-pikir kritis siswa di kelas eksperimen yang menerapkan model pembelajaran Predict Observe Explain Write lebih tinggi dari nilai rata-rata kemampuan berpikir kritis siswa kelas kontrol yang menerapkan metode ceramah bervariasi. Hal ini sesuai dengan penelitian Samosir (2010) yang menunjukkan bahwa peningkatan keterampilan berpikir kritis siswa yang mendapatkan model pembelajaran Predict Observe Ex-plain Write secara signifikan lebih tinggi dibandingkan dengan siswa yang mendapatkan model pembela-jaran konvensional. Hal ini menun-jukkan bahwa penerapan model Pre-dict Observe Explain Write dapat lebih efektif dalam meningkatkan kemam-puan berpikir kritis siswa. 


\section{Kesimpulan}

Berdasarkan hasil penelitian, dapat disimpulkan bahwa Pembelajaran Predict Observe Explain Write berpengaruh sangat nyata terhadap kemampuan berpikir kritis siswa kelas $\mathrm{X}$ SMA Negeri 2 Sukoharjo tahun pelajaran 2012/2013.

\section{Daftar Pustaka}

Adnyana, G. P. 2008. Meningkatkan Kualitas Aktivitas Belajar, Keterampilan Berpikir Kritis, dan Pemahaman Konsep Biologi Siswa Kelas X-5 SMA Negeri 1 Banjar Melalui Penerapan Model Pembelajaran Berbasis Masalah. Jurnal Pendidik-an_Kerta Mandala. Vol.1 (1): 143-159

Amri dan Ahmadi, S. 2010. Proses Pembelajaran Inovatif dan Kreatif Dalam Kelas. Jakarta: Prestasi Pustaka

Cahyadi, F. D . 2012. Penerapan Blended Learning Dalam Pembelajaran Biologi Untuk Meningkatkan Kemampuan Berpikir Kritis Siswa Kelas XI IPA 4 PUTRA SMA RSBI Pondok Pesantren Modern Islam Assalam Sukoharjo Tahun Pelajaran 2011/2012. (Skripsi Tidak Dipublikasikan: UNS Surakarta)

Depdiknas. 2006. Peraturan Menteri Pendidikan Nasional No 23 Tahun 2006. Jakarta: Depdiknas

Fachruazi. 2011. Penerapan Pembelajaran Berbasis Masalah Untuk Meningkatkan Kemampuan Berpikir Kritis dan Komunikasi Matematis Siswa Sekolah Dasar. Jurnal Pendidikan Edisi Khusus No. 1, ISSN 1412-565X

Facione. 2011. Critical Thinking: What It Is and Why It Counts. California:
Measured reason and the California academic press

Fransiska. 2009. Pembelajaran Biologi Berbasis Praktikum untuk Meningkatkan Ketrampilan Proses dan Kemampuan Berpikir Kritis Siswa SMA. Artikel Universitas Pendidikan Indonesia

Hidayat, W. 2011. Meningkatkan Kemampuan Berpikir Kritis Matematik Siswa Sekolah Menengah Atas Melalui Pembelajaran Kooperatif Tipe Think-Talk-Write. (Skripsi Tidak Dipublikasikan: Universitas Pendidikan Indonesia, Bandung)

Jensen, E. 2011. Pemelajaran Berbasis Otak Paradigma pengajaran Baru. Terj. B. Molan. Jakarta : Indeks

Johnson, E. B. 2010. CTL Contextual Teaching \& Learning Menjadikan Kegiatan Belajar-Mengajar Mengasikkan dan Bermakna Diterjemahkan Dari Contextual Teaching \& Learning: What It Iis And Why It's Hero To Stay. Bandung: Penerbit Kaifa

Lestari, P. R. 2012. Pengaruh Model Pembelajaran Experiential Learning Terhadap Penguasaan Konsep dan Kemampuan Berpikir Kritis Siswa Sma Pada Konsep Transport Membran. (Skripsi Tidak Dipublikasikan: UPI, Bandung)

Liew. 2004. The Effectiveness of Predict-Observe-Explain Technique in Diagnosing Students' Understanding of Science and Identifying their Level of Achievement. Paper presented at the annual meeting of the American Educational Research Association, San Diego

Pratama. 2012. Hubungan antara Kecenderungan Berpikir Kritis Dengan Indeks Prestasi Kumulatif (IPK) Mahasiswa Prodi Dokter FK UNDIP. (Laporan Hasil Penelitian Tidak Dipublikasikan: Universitas Diponegoro, Semarang)

Praptiwi. 2010. Pengembangan Model Pembelajaran Inkuiri Untuk Meningkatkan Keterampilan Berpikir 
Siswa pada Mata Pelajaran Sejarah SMA. (Tesis Tidak Dipublikasikan Tidak Dipublikasikan: Universitas Pendidikan Indonesia, Bandung)

Samosir, H. 2010. Model Pem-belajaran POEW untuk meningkatkan Penguasaan Konsep Kalor dan Keterampilan Berpikir Kritis Siswa SMA. (Thesis Tidak Dipublikasikan: Universitas Pendidikan Indonesia, Bandung)
Suyanto. 2012. Keefektifan Penggunaan Strategi Predict Observe Explain Untuk Meningkatkan Kemampuan Berpikir Kritis Dan Kreatif Siswa. Unnes Physics Education Journal 1 (1) 2012

Wijaya, C. 2007. Pendidikan Remedial Sarana Pengembangan Mutu Sumber Daya Manusia. Bandung: Remaja Rosdakarya 